\title{
The Enhancement of Attractiveness and Effectiveness of History Learning Using Local History Interactive Teaching Material
}

\author{
Siti Ma'unah, Nurul Umamah, Sumardi, Riza Afita Surya* \\ Faculty of Teacher Training and Education, University of Jember, Jember, Indonesia \\ *Corresponding author: uunfkipsejarah@gmail.com
}

Received October 04, 2018; Revised November 13, 2018; Accepted November 22, 2018

\begin{abstract}
Learning package used in history learning has not been exposing the content of students' surroundings or only describes national events. Learning package which only involves historical events in national light obtains high level abstraction., thus students considered history as monotonous. In addition learning package visual appearance is dominated by text pulls students feel hesitated to study. These findings based on questionnaire results of students which indicated that $79,64 \%$ have not received local history learning. Furthermore, quetionnaire results given to teachers indicated that $80 \%$ of them have not engaged local resources. This study focuses to generate valid interactive learning package of local history, attractive and effective to be utilized in history learning. This study happens to be development research engaging ADDIE model. Research subjects were 96 students of XI grade Sekolah Menengah Kejuruan in Kabupaten Jember. Instrument used were questionnaire, test, interview, observation, and documentation using qualitative and quantitative analysis. Research results show that (1) interactive learning package of local history used within history learning, content expert validation 96,74\% (very suitable), language expert validation $80 \%$ (very suitable), design expert validation 86,66\% (very suitable), (2) Interactive learning package of local history has been tested its attractiveness, during small group trial show that learning package of local history is considered attractive by $69,382 \%$, relating field trial show that local history learning package by $76,7 \%$,upon implementation using $\mathrm{T}$ test indicated significance level of 0,00 , it means there is a significance between pre test and post test. Hence, learning package of local history is considered attractive and effective to be utilized in history learning.
\end{abstract}

Keywords: attractive, effective, interactive material, local history

Cite This Article: Siti Ma'unah, Nurul Umamah, Sumardi, and Riza Afita Surya, "The Enhancement of Attractiveness and Effectiveness of History Learning Using Local History Interactive Teaching Material." American Journal of Educational Research, vol. 6, no. 11 (2018): 1531-1538. doi: 10.12691/education-6-11-11.

\section{Introduction}

Dynamic social changes and unpredictable future delivers new demands for education institutions. Schools must teach their students how to learn, think, and create. Traditional learning with one-way orientation communication does not satisfy contemporary needs for the integral personal development of students [1]. This happens due to Industrial Revolution 4.0 educational features namely complex, dialectical, and other opportunities which enhance society to be better. Industrial revolution academic prominency is convergency between human and machine, thus reduces distance among human, science, knowledge, and technology. Hence, there is a need of creative innovation in the sense of teaching and learning, one of which is interactive learning package of multimedia development that suitable towards current education circumstance.

Regarding history learning, media and learning package are necessary integrated assets both in teaching practic and strategy. History learning package beneficial in improving creativity and independency, motivation and information sharing $[2,3,4]$.

Learning package is a commincation form between educator and learner. Thus, learning package must include guidance for students in assisting them to achieve learning subjectives [5].

Relating local history, interactive local history learning package provides technical assistance for teachers in transmitting learning content and facilitates students in order to be independence learners.

The History learning material in school is arranged in the form of Indonesian History text book. The book is published nationally, so it is impossible to discuss local history in detail ([6]: 9). Local history content is considered to an effective step to examine history internationally.

According to Stafaniak's, et al [7] students who study local history of their surroundings will enhance historical interest, passion, national awarness, and social trust. The results also indicate that there is a relationship between local history and students national awareness improvement [7]. 
Commonly, local history is a collection of writings describing about towns or states created by amateur authors for local inhabitants. Local history is a concept taught as a narrative or topic refers to a certain place. Geographical location is vary for every single book and author. Research regarding local history collects all kind of past documents, both amateur or academic that did study on a same place. Those writings collection are constructing local history narration [4].

Local history teaching was being part of history curriculum had been long since 19 century. Local history in the sense of education means studying a limited area within a short time using learning access which can be accessed by students [8].

Local history teaching materials that are not available at school is the cause of history learning that introduce many historical events that only figure at the national level and even at the world level, but often forget and less introduce historical events at the local level ([6]: 1). The History learning discuss about historical relics that are far and not common from the students environment and less discuss about historical heritage in term of surrounding environment. The Educators also have never compiled local history teaching material due to time and cost limitations. Students only use textbook issued that published by the government by borrowing at the library, without other supporting teaching materials.

History learning typically describes historical heritage which is out of sight, yet it rarely discusses historical findings nearby students environment. Teachers also have not been designed local history learning package due to time and cost. Students solely utilized texbooks from library without other support.

The History learning discuss about historical relics that are far and not common from the students environment and less discuss about historical heritage in term of surrounding environment. The Educators also have never compiled local history teaching material due to time and cost limitations. Students only use textbook issued that published by the government by borrowing at the library, without other supporting teaching materials.

Teaching material that emphasizes national historical event is have a very high level of abstraction, because something that is learned is far from the life and environment of students. Therefore, student's consideration of learning history is not important and is not interesting. Historical event are only events that happend in the past that are foreign for student and different from what is experienced in the present.

The physical appearance of printed teaching materials that display limited images was made history learning to be unattractive. The result of the questionnaire on learning problem indicates that the main factor of the student's low interest is teaching material that does not utilize various media. The student assessed the teaching material used by too much text. In this case, print teaching materials have the disadvantage of being static and cannot display simulations. Print teaching materials make the learning process less attractive, less interactive and cannot delivered historical messages through three dimensions picture, videos, and animation. Students want a teaching material with various media (multimedia), so that it varies and learning activity can be easier and more enjoyable.
Since the student is be part of $\mathrm{Z}$ Generation is be the tendency of the preferness the use of technology as the learning media. Nowadays, students in this generation prefer to communicate with the technology they have rather than spend time face to face with other people ([9]: 20).

Gen Z learners are able to adapt towards anywhere learning environment, where they able to fugure out their ability as part of self-reliance and self-education. In the other hand, despite Gen $\mathrm{Z}$ are highly independent, they appreciate the appearance of interaction and collaboration $[10,11]$.

The characteristics of $\mathrm{Z}$ Generation bring implications in the education process, including history learning. During the learning activity, Students will prefer to interact with technology rather than with educators. Therefore, educators must be able to utilize technology in history learning as a learning media, including in compiling teaching material. The teaching material that does not utilize technology will be considered boring or unattractive by students.

Based on the Identification of the problems above, shows that the teaching materials used in history learning are not attractive. The reason is because the material just discuss about the national context and does not connect with events at the local level, and also because of the media used in teaching material does not vary. Unattractive teaching material is the factor that made history learning to be ineffective. This can be analyzed from the low valuse result of students. Therefore, in the process of learning history requires local history teaching materials that are equipped with varied media displays or interactive multimedia.

History learning utilizing interactive package puts teacher in responsibility in planning, teaching, and facilitating integrated learning series with technology. In the other hand, students do construct, demonstrate, and collaborate with peers to aquire knowledge (Sessoms, 2008).

Students find easier to study using their own learning style. Learning style of learner is highly correlated to learning sources preferences of interactive learning [2]. Interactive learning package is essential for students, as it guides them how to learn, how to be independent learner and how to communicate with peers to find relevant information [1,2].

The Teaching material that contain of local historical can draw the historical event that abstract in order appear more real to students. This is because the local history also can show the relationship between abstract historical events with the student's daily life, so it can improve the perspective of students who consider that history learning activity is a useless learning ([12]: 233; [13]: 148). Therefore, students become actively involved in history learning activity. These teaching materials can also increase student's interest in learning, because what they learn feels useful and it doesn't feel as the past events that are not related to them.

Local history material that is compiled into interactive teaching materials the can attract the student's attention as $\mathrm{Z}$ Generation who interest to technology. Interactive teaching material is teaching material that use the nonprinted material which consists of more than one media 
and this is interactive, means that it is designed to be able to dictate the user back to carry out an activity, so it can be as the control of the user and orderer to do so ([14]: 329).

This teaching material is equipped by a controller and can be used by users. So that users can choose what they want to do in the next process, on the contrary, the program is also designed to be able to do command back to the user to do an activity ([14]: 329).

Interactivity is a learning system design which generates learning effectiveness and as a fundamental mechanism in knowledge acquisition. Interactive learning system possess a mechanism which enables student to behave in a certain assignment and receive relevant feedback (Westerlund, 2013).

This technology is used to provide information in a more attractive form, so that it can attract the attention of users, and provide a more active and independent learning experience. Interactive teaching materials are also able to present historical relics of environment around students to the classroom through video and picture. While considering the exploration of the surrounding environment is difficult because of the limited time.

The research conducted by Bayraktur and Altun [15] With the tittle The Effec of Multimedia Design Types on Learners' Recall Performance With Varying Short Term Memory Spans, shows that varied interactive designs media are more effective in attracting and maintaining student's attention. This is because the presentation of information with varied media that is interactive can focus student's attention and maintain it during interaction. Thus, the preparation of material based on local history will be more interesting and effective if it is in the form of interactive teaching materials.

\section{Research Methodology}

This research is a development research using ADDIE development model. The product development with the ADDIE model consists of five steps that are analysis, design, development, implementation and evaluations ([16]: 2, [17]: 38). Analysis relates to the analysis of environmental work situation, so that what the product need to be developed can be found Design is a product design activity that adjusted with the needs. Development is an activity of making and testing the product. In the develop phase, formative revision is also carried out. Implementation is an activity using the product. Evaluation is an activity to assess whether every step of the activities and product made is in accordance with the specification. The purpose of the evaluation phase is to assess the development process and the quality of learning product, both before and after implementation

The subjects of this study were 96 students in XI grade consisting of three state vocational high schools in Jember Regency, there are SMK N 1 Jember, SMK N 2 Jember, and SMK N 4 Jember. The instruments used were questionnaire, interview, observation, and documentation using qualitative and quantitative data analysis. Qualitative analysis data is obtained from the interview, observation, questionnaire, expert advice and documentation has been captured. Then, these data were analyzed descriptively and qualitatively. In this study, quantitative analysis uses questionnaire and test instrument given during validation test, individual test, small group test, field test and implementation. Then, questionnaire instrument data result is analyzed using the average and percentage analysis techniques to determine the feasibility and attractiveness of local history interactive learning material. The data from the result of the pre-test and posttest were analyzed using the $t$ test and used the relative effectiveness formula to determine the effectiveness of the local history interactive material.

\section{Result and Discussion}

\subsection{Result and Discussion of Expert Validation}

\subsubsection{Result and Discussion of Material Expert Validation}

The development validation of material expert was carried out twice. This is done because the expert validation in the first stage shows the percentage of 56, $279 \%$, which is stated in the qualification "good enough" if it is consulted on the content feasibility table of the local history interactive teaching material. Therefore, it is necessary to do a revision which is then re-validated. The result of the material validation assessment in the first stage is in good enough qualification because there are some weaknesses in the interactive history teaching materials in these aspects.

The lowest result of material expert validation is found in the aspect of material coverage, with the result number 3 that show good qualification. This is because the the material and example do not reflect the substance of the material contained. For instance, the learning activity chapter 4 that discuss about the impact of Western country colonial education. According to the material expert, in order the student can describe the impact of Western colonial education. It must be explained Indonesia condition before the arrival of Western nations. Thus, students will be able to distinguish between education in Indonesia before Western colonialism and during the Western colonialism, so the student can conclude its impact.

The aspect of material accuracy gets a better value than the aspect of material coverage that is 3.75 . However, this value has not achieved good qualification that is 4 . The low aspect of material accuracy is due to pictures references on teaching material that use internet resources and the year of schools establishment in Jember that are inaccurate. The current term aspect and contextuality aspect gets the highest score that is 3.78. This is because local history interactive teaching materials have described the impact of Western nation colonization by giving examples of the student's surrounding environment especially in Jember. The discussion about the western nation colonization impact was also analyzed until the effect of it to the present. Thus, students be able to get the material that is contextual and current.

The aspect of presentation technique also obtained the lowest score that is 3 , with good enough qualification. The low value in this aspect is caused by the systematical 
consistency and the coherent for the concept is does no really good related to the chronological description of the material. In the aspect material history, the material must be described chronologically and systematically according to time.

Basically, the completeness of the presentation is complete, the contain includes title, preface, introduction, table of content, $\mathrm{KI}$ and $\mathrm{KD}$, the guidence for using instructional material, main maping concept, illustration, conclussion, glossary, exercise, evaluation and bibliography. But in some components, there are some weaknesses so that the value obtained is just 3.07, with enough good qualification. The lowest value is in the summary and main maping, which is obtained 2. This is because the summary with the material description is inconsistent and in the main maping has many typographical errors. In addition, the other components also have typographical errors.

Based on the assessment above, the material expert gave several suggestions, that are (1) achronological description of teaching material need to be corrected systematically (2) the deepening of the references used, (3) the images displayed is suggested to not use internet sources, (4) the consistency of writing should be improved, (5) The using of the terminology should be carefully, (6) The bibliography structure must be in accordance with the scientific work guide book at the University of Jember (7) The use of language is accordence with EYD, (8) There are still some typo words. Based on these suggestions, the developer made several improvements. After the material is revised, then the feasibility of the material is tested again by the material expert.

The second validation result shows a value with a percentage of $96.74 \%$, if it consulted with the feasibility table is obtained very good qualification. This is because each aspect that has weaknesses has been corrected. The improvement result can be seen from the value of each aspect. The aspect of the material coverage gained and obtained to the score score 5 (very good), the accuracy of the material obtained score of 4.75 (good), the latest and contextual obtained score of 4.8 (good), the presentation technique obtained score of 5 (very good), the presentation of learning obtained score of 4.98 (good), and completeness of presentation obtained score of 4.67 (good). The advice of the material expert on the second validation is the improvement of some typo words.

\subsubsection{Result and Discussion of Linguist}

The result of Expert validation is obtained the percentage of $80 \%$, if consulted with the table the feasibility of language using obtained "good" qualification result. This is because in every aspect of the assessment of language use, the score of 4 is obtained, with good qualification result. According to linguists, the use of language is in accordance with the level of student's development because language that used for both to explain concept and illustration of concept application is in accordance with the emotional maturity of students accompanied by illustration that illustrate the concept of the nearest environment to the global environment.

The language used in teaching material is communicative. This aspect gained good qualification because the message conveyed in the teaching material was presented in an interesting and also common Indonesia language writing communication. Linguist was also assessed that illustrations (map, image, video, animation used to explain the material in each chapter are relevant to the message contained in the discourse.

The dialogical and interactive aspect obtained score of 4 with good qualification result. This is because the language used in teaching material has fostered a sense of happiness when student read it, so that it can encourage student to read it thoroughly. In addition, the language used can stimulate the student questioning and seeking answer of teaching material discourse.

The straightforward aspect obtained score of 4 with good qualification because the sentence used by the developer is based on the correct sentence in Indonesia language standarization. The use of the term is also in accordance with the KBBI and standardized upon scientific term. The language used in instructional material has been based on systematic structure that can be identified by the structure of chapter, sub-chapter, paragraph that correlate with integrity meaning.

The weakness of the language use in teaching material is in the aspect of conformity with the Indonesia language standardized rules so that it does not get a very good score. In the interactive history teaching material for local history, there are some errors spelling, typo word and grammar in every sheet. Therefore, linguists suggest "Spelling and typo need to be repaired and checked again". The developer then corrects the local history interactive teaching material by checking and correcting the words of each page.

\subsubsection{Result and Discussion of Design Expert}

The result of design validation obtained a value with a percentage of $86.66 \%$, if consulted in the feasibility table of the interactive teaching material design of local history is in "very good" qualification. The good qualification is obtained from the designer's assessment because the local history interactive teaching material has fulfilled the requirement of good quality teaching material base on learning design perspective. It can be identified from teaching material aspects that obtained the good score.

The first aspect is interactive multimedia design. The multimedia aspect is obtained the score of 4.32 with "good" qualification. According to design expert, all components in interactive multimedia aspect are already exists in teaching material. Design expert explain that interactive local history learning materials are , (1) easy to use and operate, (2) the completeness learning material is very good, (3) language skills that can invite users to do something good, (4) the teaching material also allow student learn independently because there are complete guidence for using instructional materials, such us material, evaluation and key answer, (5) The components of multimedia material teaching are complete because it can be identified from the content exist such as animation, video, photo or drawing, table and main maping. The component is harmoniously integrated into multimedia unity. Associated with multimedia features, the expert desain gives some suggestions (1) the selection of text fonts must be used Tahoma / Arial because using Times New Roman will make it difficult for students to read it, (2) Pay attention to the contrasting colors principle so that 
teaching material looks more visible, so student feel interested in using it, (3) The menus should be given number to make it easier for student, (4) some letters are broken, a resolution should be added, (5) placement of number in paragraph, (6) video displays and material made in full screen to make it more visible. These deficiencies that make the value result of expert validation do not get $100 \%$ percetege or perfect score, even though both are in very good qualification. Therefore, the developer then revised to cover the weakness.

The design aspect of teaching material is obtained score of 4.2 which mean in good qualification. According to expert design, local history interactive teaching material have the ability to attract student's attention, develop student's learning motivation, use interesting illustration, use clear language, there is correlation with the learning material, and avoid vague learning concept. The aspect of local history learning design also has a good qualification value of 4.28. The design expert explained that in the local history interactive teaching material. The steps of learning local history in historical subject have been observed. There have been apperception, observation by student, group division, information extraction, the process of communicating, giving conclusion, evaluation and reflection.

\subsection{Result and Discussion in the Attractiveness of Local History Interactive Teaching Material}

\subsubsection{Result and Discussion of Attractiveness in Local History Interactive Teaching Material in Small Group Test}

The result of the questionnaire response and the value of student assessment attractiveness of local history interactive teaching material shows in SMK $\mathrm{N} 1$ with a percentage of $70.740 \%$, if it consulted with the attractiveness table of local history interactive teaching material included in the high qualification.

The attractiveness of interactive learning material for local history is measured from several aspects such the attractiveness of cover design, structural design, color design, content description, image illustration, main maping, table and video illustration. From these aspects, the lowest value is found in the structural design aspect of local history interactive teaching material with a percentage of $66.6 \%$ with quite attractive qualification. The aspect of the main maping cocept also obtained quite attractive qualification with a percentage of $68.3 \%$. The attractiveness aspect is obtained "attractive" qualification. The highest score obtained is in picture illustration, which is $80 \%$ with "attractive" qualification, and the video illustration aspect that get $76.6 \%$ with "attractive" qualification. Thus, it can be concluded that the structural design and main maping illustration aspect are considered quite attractive by students, while other aspects are considered attractive. While what is considered most attractive aspect is the images and video illustration.

The analysis is in accordance with the student's response who stated that interactive local history teaching materials are interesting to use. But there are some suggestions given by students, such as to enlarge the video slide show. To improve the quality of local history interactive learning material, then the developer fixes it by enlarging the video slide show.

Small group tests were also conducted at SMK N 2 Jember. The result of the questionnaire response and student assessment of the attractiveness level of local history interactive teaching material shows with a percentage of $68,148 \%$, if it is consulted with the attractiveness table of local history interactive teaching material including in high attractiveness qualification. These results are lower than the percentage of the attractiveness level in SMK N 1 Jember although both are in attractive qualification. This shows that students in SMK N 1 Jember are more interested in using local history interactive material. Students in SMK N 2 Jember are quite interested in color design, table design, and video design in teaching material. Besides, all aspects of the attractiveness of teaching materials are in attractive qualification. The highest score is the illustration aspect with $73.3 \%$, and cover design with the percentage of $71.6 \%$. Thus, among several aspects of the attractiveness of the teaching material of students in SMK $\mathrm{N} 2$ Jember are most intereste in the image illustration and cover design. Educator at SMK N 2 Jember suggests that there are some terms that are less understandable. Therefore, the developer then fixes interactive teaching material by multiplying terms in the glossary.

Small group test were also conducted at SMK N 4 Jember. The result of the questionnaire response and student assessment of the attractiveness level of local history interactive teaching material shows with a percentage of $69,259 \%$, if consulted with the attractiveness table is in high attractiveness qualification. The lowest score is in content description aspect of teaching material with a percentage of $63.3 \%$ and it is quite attractive, while other aspects are in attractive qualification. The highest score are in the illustration image and video aspects with a percentage of $73.3 \%$, and it is include in attractive qualification. Thus, the weaknesses in the local history interactive teaching material according to students of SMK N 4 Jember are in the aspect of the description content. The most interesting aspect of local history interactive teaching materials are in the illustration aspect of images and videos. This is consistent with the response of students who consider that the explanation of the video display and illustration are good and very interesting, and and can enlarge knowledge.

Based on the discussion above, it can be concluded that students in three schools considered that the most attractive aspect of local history interactive teaching material were illustration of picture and video. Regarding which the most unattractive aspect aspect is cannot be generalized because each student in each school has different assessment.

\subsubsection{Discussion of Attractive Result of Local History Interactive Teaching Material in Field Test}

Field test in this development research were conducted in three schools that are in SMK N 1 Jember, SMK N 2 Jember, SMK N 4 Jember with 96 subjects. At this stage students answer response questionnaire and student's assessment toward the attractiveness of local history interactive teaching material. Questionnaire score result is then analyzed and it obtained a percentage of $76.689 \%$, if consulted with the attractiveness criteria table of local 
history interactive teaching material is in high attractive qualification. The result is obtained because in every aspect of attractiveness such as aspect of cover design, structure design, color design, description, content of teaching material, illustration of drawing, main maping, table, and video are obtained attractive qualifications. The highest score is obtained by the attractiveness aspect of video illustration with a percentage of $82,5 \%$. Thus, student assess that video display is the most attractive aspect in local history interactive teaching material rather than other aspects.

This results suitable to Tomljenovic's [1] who examined the effect of interactive teaching and learning within visual art in primary school "An Interactive Approach to Learning and Teaching in Visual Arts Education.” Those findings reveal that there is significance between traditional approach teaching compared to interactive approach teaching and learning. After conducting interactive learning, students ability, technique, and creativity increase compared to control group. Another discovery is interactive learning improves critical and creativity capacity by engaging active, independent student-centered, investigative, and cooperative teaching.

These results are in accordance with the learning condition during the field test. Students are very enthusiastic in paying attention to the video that showing the impact of the western colonialism in Jember. Student's interest can be identified from the comment and suggestion given. 25 students of 51 students gave feedback in comment form that local history interactive teaching materials were very interesting to use, 15 students stated that local history interactive teaching materials were attractive to use, and 12 students stated that local history interactive teaching materials were quite attractive to use. Thus, most students feel that local history interactive teaching materials are very attractive to use.

\subsubsection{Result and Discussion in the Attractiveness of Local History Interactive Teaching Material during the Implementation Phase}

The implementation phase in this development research was conducted in three schools, that are in SMK N 1 Jember, SMK N 2 Jember, SMK N 4 Jember with 96 subjects. At this stage, students fill out questionnaire of response and student's assessment toward the attractiveness of local history interactive teaching material. Questionnaire score result then analyzed and it obtained in a percentage of $82.152 \%$, if consulted with the attractiveness criteria table of local history interactive teaching material is in high attractive qualification. The attractiveness of local history interactive teaching materials at the implementation stage has increased compared to the field testing phase. This is because every attractiveness aspect in the teaching material is always increase, it has been improved with the percentage. Some aspects of attractiveness even experience an increase from attractive qualifications to very attractive qualifications, such as aspects of color design, content description, illustration picture, and video illustration. This is because developers always make revisions related to deficiencies or weaknesses in local history interactive teaching material. The highest score is in the aspect of video illustration with a percentage of $86.25 \%$. Based on the description above, it can be concluded that from some aspects of the attractiveness of teaching material, the most interesting aspect for students is video illustration.

\subsection{Result and Discussion in Effectiveness of Local History Interactive Teaching Material}

The discussion in result of the effectiveness of teaching material includes the effectiveness of local history interactive teaching material in small group test, field test, and implementation phase. In the following, it will give detail the explanation.

\subsubsection{Result and Discussion in Effectiveness of Local History Interactive Teaching Material in Small Group Test}

The results of the small group test show that in each school, the local history interactive teaching material is effectively used in history learning. These results are based on the t-test which the result is in a significance level of 0.00 . The result of the pre test and post test were then analyzed for their relative effectiveness. The result showed a percentage of 63 , which $182 \%$ is included in the medium effectiveness. Thus, interesting local history instructional materials have an impact on student learning outcome and make history learning activity become effective. The effectiveness of learning using interactive local history teaching material is also related to the advantages of these teaching materials. For example interactive teaching material can overcome learning styles. Thus, students will be able to learn with their own learning style. Learning with local history interactive teaching material also has several advantages such as (1) the learning activity will be more meaningful so it can invite students to be more active in learning activity, (2) it provide larger knowledge to learn specific topic, (3) it can elaborate various types of material (Munandi, 2013: 222-223). These advantages allow student's learning outcome to be more optimal than before.

The use of effective local history interactive teaching material in history learning is also consistent with previous research that arranged by Arni Nurmarizai [18] with the tittle "The Development of Activity-Based Teaching Material with Interactive CD Media on Sensory Hearing and Sonar Systes" which concluded that activity-based teaching material with interactive CD media in junior high school learning activity under the science course chapter about the sensory material and the sonar system is feasible and practical and effective to be used in the learning process. Similar research was also carried out by Abdullah M. Alhomaidan et al [19] with the title "The Effect of Interactive-Image Elaboration on the Acquisition of Foreign Language Vocabulary". Interactive Image is one type of interactive multimedia. This study shows that Interactive-Image use is more effective than repetition strategies. Thus, the local history interactive teaching material is truly effective in history learning activity.

\subsubsection{Result and Discussion in the Effectiveness of Local History Interactive Teaching Material in Field Test}

In each school, the result of the field test show that local history interactive teaching materals are effectively used in history learning activity. These results are based 
on the t-test which results in a significance level of 0.00 However, the effectiveness analysis is relatively high when compared to the small group test which is obtained a percentage of $67.106 \%$.The effectiveness enhancement increasingly gives confidence that local history interactive teaching materials are truly effective in learning history. The effectiveness of the use of interactive learning materials in local history is supported by the positive attitude of the students towards the teaching materials. This can be identified from the feedback of student's suggestions in the field phase test, that 25 students of 51 students commented that local history interactive teaching materials are very interesting to use, 15 students stated that local history interactive teaching materials were attractive to use, and 12 students stated that local history interactive teaching materials are quite attractive to use.

This study associates to Delialioglu's et al [20] which assessed students' perception towards interactive learning dimension effectiveness upon blended learning "Students' Perceptions on Effective Dimensions of Interactive Learning in Blended Learning Environment.” This study engaged interactive website of constructivism based learning. The results indicate that students were able to process plentyful of information and interactive website of blended learning based promoted students to examine, access, and manage information [20].

The other research conducted by Rosida [21] with the title "The Effectiveness of Using Interactive E-Book Teaching Material to Improve Critical Thinking Skill" concluded that the application of interactive e-book teaching material in learning was effective enough to improve student's critical thinking skill. The similar research was also carried out by Johannes Huwer et al [22] with the title "The School Book 4.0: The Multitouch Learning Book as a Learning Companion". Multitouch Learning Book is an e-book with interactive integrated multimedia content. In this study, the result indicated that the average value of the experimental group test is higher than the control group. It means that the experimental group experienced performance greater improvement rather than the control group. Thus, chemistry learning is more effective when using Multitouch Learning Book.

Interactive learning based approach does not only deliver positive impact upon students, but also teachera. This refers to Li's et al [23] namely; 1) teacher who conducts self-development using interactive learning package is highly motivated to make achievements and 2) teacher engaging interactive learning package has higher motivation [23]. Positive affect derived of Li's research was supported by Xhemajli [24] states teacher role in utilizing interactive learning proposes not only education and vocation aspect, but also as designer, educator, and tutor [24]. This study was strength the result of the use of local history interactive teaching material in history learning that has proven effective to use.

\subsubsection{Result and Discussion in the Effectiveness of Local History Interactive Teaching Material in Implementation Phase}

The result of the implementation shows that in each school, the local history interactive teaching materials are effectively used in history learning. These results are based on the t-test which results in a significance level of
0.00. However, the effectiveness analysis is relatively increased when compared to the field test, which is obtained a percentage of $72.697 \%$. In the implementation phase, students also showed a positive attitude. It was one of factor that supports the result of relative effectiveness enhancement. This can be identified from the student's feedback through suggestion during the field phase test. The 20 students of the 42 students who commented that the local history interactive teaching material were very attractive to use, 13 students stated that the interactive local history teaching materials were attractive to use, and 9 students stated that local history interactive teaching materials are quite attractive to use. In addition, the student's learning activities during the implementation stage are also enhanced especially during the working on tasks and evaluation activities. This is suitable with the opinion of Munandi ([25]: 222-223) which states that interactive teaching material for local history influence student to be more active in learning activity. Previous research conducted by Coiru Munib [25] with the title "The Effectiveness of the Use of Interactive Multimedia-Based Teaching Material on Student Learning Achievement in XI IPS Economic Class of State Senior High School Srengat 1 of Blitar District" concluded that there were differences in the use of interactive multimedia-based teaching material to student learning achievement. In other words, it effectively used in learning activity. A similar study was also carried out by A. Pio Albina [26] entitled "Effectiveness of E-content in Teaching of Mathematics Education among B.Ed. Student-teachers". In this study, E-content is in the form of Multimedia or hypermedia. This study focused on knowing the effectiveness of e-content in teaching mathematics education. The result showed that there are significant differences between the control and experimental group. This finding confirms that effective E-content is used in Mathematics learning. This finding also ensures that e-content has the potential to improve student's learning opportunities and become an important learning media to use. This study recommends e-content that uses interactive multimedia also needs to be used in other subjects. Thus, the use of interactive multimedia is truly effective in learning, including in learning history.

\section{Conclusion and Suggestion}

The results show that there is enhancement in attractiveness and effectiveness in history learning by using local history interactive teaching material from the small group test stage, field test to the implementation stage. In the small group test stage showed the level of attractiveness of students with a percentage of $69,382 \%$. In the field test shows the level of student's interest is high with a percentage of $76.689 \%$. In the implementation phase shows the level of student's interest is high with a percentage of $82.152 \%$. This research shows that the local history interactive teaching material have been tested for student's interest and can attract the attention of students to study history. Local history interactive teaching materials are also effective in increasing student's knowledge of local history in Jember. in phase of the small group test obtained with a percentage score of 
$63.182 \%$ which included the category of "medium effectiveness" in the field test phase received a percentage of $67.106 \%$ which included the category "medium effectiveness" and at the implementation stage obtained 72 , $678 \%$ included in the "high effectiveness" category.

Thus, local history interactive teaching material in learning activity becomes very important. Learning materials that are elaborated with interactive teaching material will help students to conclude abstract ideas, so that it will facilitate student in learning activity. The use of interactive teaching materials also needs to be used in other subjects especially for historical subject because this interactive teaching material contains only local historical material in Jember, it is necessary to develop interactive teaching material containing other material.

\section{References}

[1] Tomljenovic, Z. (2015). An Interactive Approach to Learning and Teaching in Visual Arts Education. Center for Educational Policy Studies Journal, 5, 73-93.

[2] Jamwal, G. (2012). Effective use of Interactive Learning Modules in Classroom Study for Computer Science Education.

[3] Magro, G., Marcelino, M. J., \& De Carvalho, J. R. (2014). Improving History Learning Through Cultural Heritage, Local History and Technology, 34-40.

[4] Pasternak, S. (2009). A New Vision of Local History Narrative: Writing History in Cummington, Massachusetts, (February).

[5] Sawangsri, B. (2016). Learning Package by Means of the Inductive Teaching with Group Process. Universal Journal of Educational Research, 4(3), 618-621.

[6] Hariyono. Sejarah Lokal: mengenal yang dekat, memperluas wawasan, dalam acara Seminar Nasional Sejarah Lokal: Tantangan dan Masa Depan, FIS UM, Malang.

[7] Stefaniak, A., Bilewicz, M., \& Lewicka, M. (2017). The merits of teaching local history: Increased place attachment enhances civic engagement and social trust. Journal of Environmental Psychology, 51, 217-225.

[8] Aktekin, Semih. 2010. The Place of Local History in the Secondary History Education. Journal of Theory and Practice in Education, 6 (1): 86-105.

[9] Santoso. E.T., Raising Children In Digital Era. Elexmedia Komputindo, Jakarta, 2015

[10] Noble \& College. 2017. Generation Z. USA: Barnes \& College, Inc. Diakses pada 15 Oktober 2018 dari https://www.bncollege.com/wp-content/uploads/2018/09/Gen-ZReport.pdf.
[11] Umamah, Nurul. 2017. Teacher, Innovative Instructional Design and a Good Character in Information Era, Proceeding of International Seminar Education for Nation Character Building at STKP PGRI Tulungagung.

[12] Crocco, M. S., \& Marino, M. P. (2017). Promoting inquiryoriented teacher preparation in social studies through the use of local history. Journal of Social Studies Research, 41(1), 1-10.

[13] Mitchell, K., and Sarah, E., "Engaging Student Throught Mapping Local History”, Journal NIIH Publlic Access, 111 (4), 148-157, July 2012.

[14] Prastowo, A., Panduan Kreatif Membuat Bahan Ajar Inovatif (menciptakan metode pembelajaran yang menarik dan menyenangkan), Diva Press, Yogyakarta, 2013.

[15] Bayraktar, D.M., and Altun, A., "The Effect Of Multimedia Design Types On Learners' Recall Performances With Varying Short Term Memory Spans”, Jurnal Multimedia Tools Appl, Vol 71 (3), 1201-1213, August 2014.

[16] Branch, R.M., Instructionl Design: The ADDIE Approach, Springer, NewYork, 2010.

[17] Sugiyon. Metode Penelitian dan Pendidikan: Pendekatan Kuantitatif, Kualitatif, dan R\& D, Alfabeta, Bandung, 2016.

[18] Nurmariza, A. 2016. Pengembangan Bahan Ajar Berbasis Aktivitas Dengan Media CD Interaktif Pada Materi Indera Pendengaran Dan Sistem Sonar. Tidak diterbitkan. Tesis. Surabaya: Universitas Negeri Surabaya.

[19] Alhomai, A.M.A., Ashamry, A.K., Almuzany, S.I., and Almutawa, T.M., "The Effect of Interactive-Image Elaboration on the Acquisition of Foreign Language Vocabulary", Journal of Linguistics and Literature, 2 (1), 25-29, August 2018.

[20] Delialioglu, Omer \& Yildirim. 2007. Student's Perceptions on Effective Dimensions of Interactive Learning in a Blended Learning Environment, Educational Technology \& Society,10 (2), 133-146.

[21] Rosida. 2016. Efektivitas Penggunaan Bahan Ajar E-Book Interaktif Dalam Menumbuhkan Keterampilan Berpikir Kritis. Tidak diterbitkan. Tesis. Lampung: FKIP UNILA.

[22] Huwer, J., Bock, A., Seibert, J., "The School Book 4.0: The Multitouch Learning Book as a Learning Companion”, American Journal of Educational Research, 6 (6), 763-772, May 2018.

[23] Li, S. (2018). The Influence of Interactive Learning Materials on Self-Regulated Learning and Learning Satisfaction of Primary School Teachers in Mongolia, 1-19.

[24] Xhemajli, Arbona. 2016. The Role of the Teacher in Interactive Teaching, International Journal of Cognitive Research in Science, Engineering and Education (IJCRSEE), 4 (1).

[25] Munib, C. 2015. Efektivitas Penggunaan Bahan Ajar Berbasis Multimedia Interaktif Terhadap Prestasi Belajar Siswa Mata Pelajaran Ekonomi Kelas XI IPS SMA Negeri 1 Srengat Kecamatan Srengat Kabupaten Blitar. Tidak diterbitkan. Skripsi. Malang: Universitas Negeri Malang.

[26] Albina, A.P., "Effectiveness of E-content in Teaching of Mathematics Education among B.Ed. Student-Teachers", American Journal of Educational Research, 6 ( 7), 1021-1028, July 2018. 